\author{
N. Özhatay, M. Koçyiğit, S. Yüzbaşıoğlu \& B. Gürdal
}

\title{
Mediterranean flora and its conservation in Turkey: with special reference to Monocot geophytes
}

\begin{abstract}
Özhatay, N., Koçyiğit, M., Yüzbaşığlu, S. \& Gürdal, B.: Mediterranean flora and its conservation in Turkey: with special reference to Monocot geophytes. — Fl. Medit. 23: 195-208. 2013. - ISSN: 1120-4052 printed, 2240-4538 online.

Mediterranean phytogeographical region of Turkey covers western and southern Turkey. It boats the highest number of endemic taxa and endemism is concentrated to certain specific areas notable Amanos Mountain, Central Taurus Mountain, Taşeli Plateau, Bolkardağı, Aladağlar and SW Anatolia. For the geophyte flora point of view about 1060 taxa occur in Turkey of which 600 taxa are belonging to petaloid monocots. After publication of the second supplement of Flora Turkey during 2000-2013 years, about 900 taxa published either are new taxa or new records. 52 taxa of these additional taxa distributed Mediterranean floristic region. The four main genera are; Crocus with 26 taxa, Allium with 8 taxa, Ophyrs with 10 taxa, and Ornithogalum with 9 taxa.
\end{abstract}

Key words: Petaloid monocots, geophyte, Mediterranean, Turkey.

\section{Introduction}

Turkey is a large peninsula with a land surface of $779.452 \mathrm{~km}^{2}$. It is bordered by three seas and extends across both Europe and Asia. The total area of Turkey-inEurope (Thrace, lying to the north of the Dardanelles and Bosporus) is $23.500 \mathrm{~km}^{2}$. Lying between $36^{\prime} \mathrm{N}$ and $42^{\prime} \mathrm{N}$. Turkey boats three different climates: continental, oceanic and Mediterranean. The northern shores are subject to an oceanic climate, with the mountain region of North-east Anatolia receiving the heaviest rainfall of anywhere in Turkey. In the western Black Sea region where a drier climate prevails, typical Euxine forests are rare and replaced by a coastal strip of Mediterranean vegetation. Western and southern Anatolia has a typically Mediterranean climate, with mild wet winters and long, hot summers at low altitude. The Central and Eastern part of Anatolia has a continental climate with lower levels of precipitation than in the Mediterranean region. Country is divided into 7 geographical regions (Fig 1). 


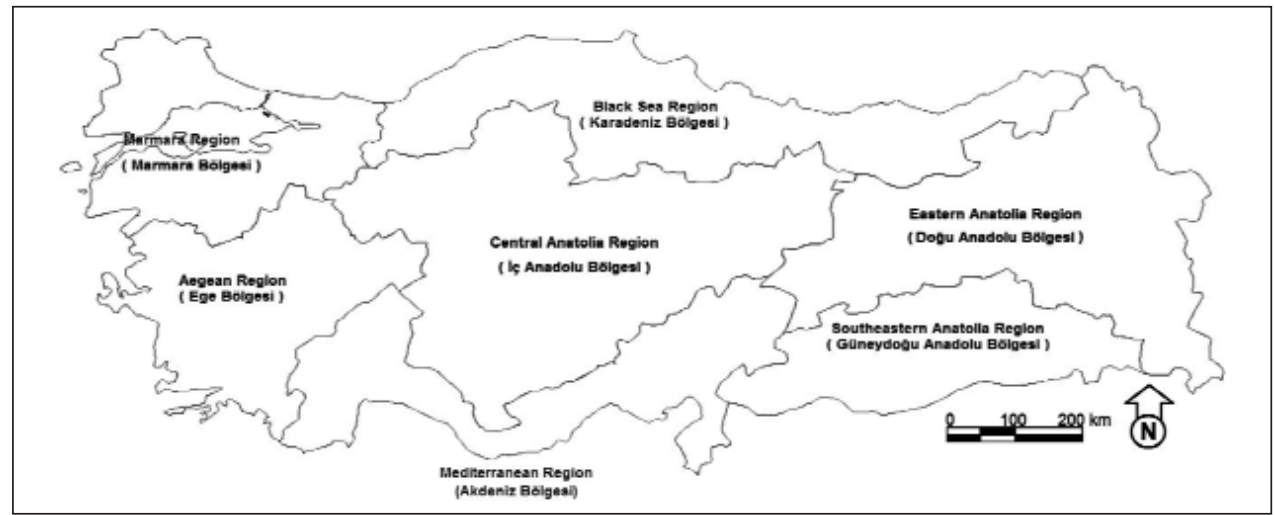

Fig. 1. Turkey's seven geographical regions.

\section{Phytogeographical (Floristic) Regions}

Turkey falls within three distinctive phytogeographical regions that are tie in closely with the three climatic zones, and these are keys to understanding the floristic richness of Turkey (Fig. 2):

I. Euro-Siberian Phytogeoraphical Region: This region extends across North Anatolia immediately south of the Black Sea coast from Y1ldız Mountains at the Bulgarian border, to Georgia. Within Turkey, the Euro-Siberian region is largely represented by the Euxine sub-region.

II. Mediterranean Phytogeographical Region: This phytogeographical region covers western and southern Turkey with all Turkish Mediterranean vegetation belonging to the East Mediterranean province. Maquis, phrygana and garrigue scrub communities typify much of the vegetation at below $1000 \mathrm{~m}$, with a notable abundance of both bulbous and annual therophyte species. On deeper soils, substantial areas of open and closed high forest communities prevail. At low altitude Pinus brutia, is the dominant tree species, with more localized stands of rarer species such as Liquidambar orientalis.

III. Iran-Turan Phytogeographical Region: This region occupying Central and East Anatolia is the largest of the three phytogeographical regions in Turkey. Its vegetation consists of extensive plain and montane steppe communities, dominated by herbaceous and suffruticose perennials, with an increasing preponderance of scrub and incipient forest communities at the margins of inner and outer Anatolia.

\section{The Anatolian Diagonal}

Peter Davis proposed the idea of a phytogeographic boundary across the heart of Turkey, running in an oblique belt form. Bayburt-Gümüşhane area is in the north, southwards towards are observed the Amanos and Central Taurus Mountains. This boundary-of which he coined the term 'Anatolian Diagonal'-was a clear barrier, with significant numbers of species concentrated either west or east of this belt, but many species not staying across it (Fig. 2). 


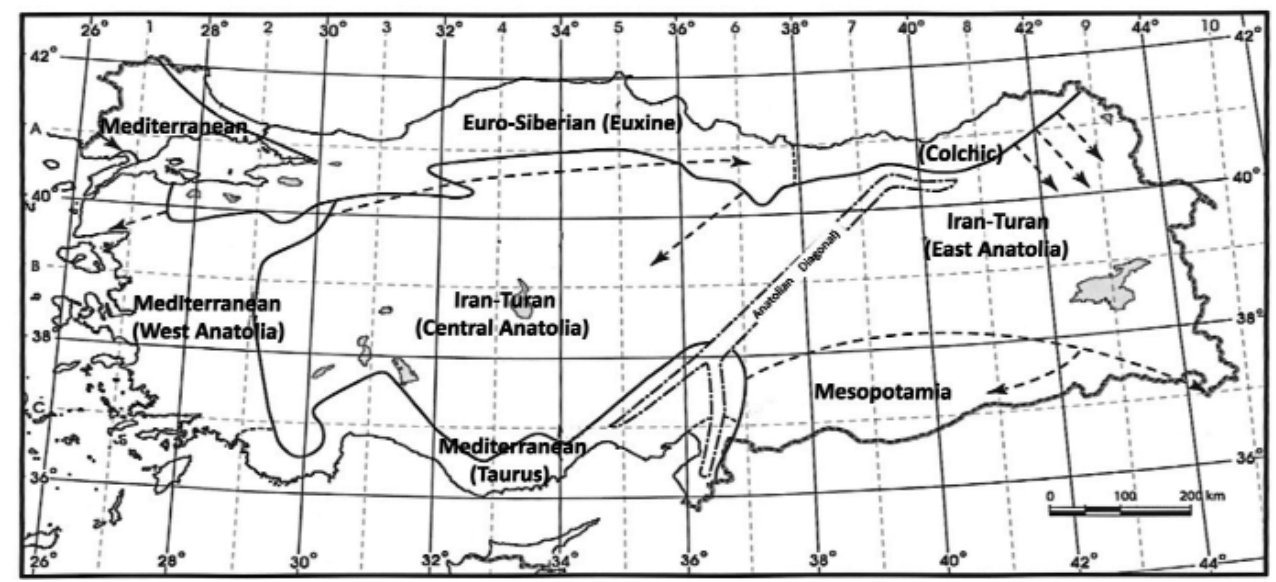

Fig. 2. The phytogeographical regions of Turkey and the Anatolian Diagonal (after Davis \& al. 1971).

\section{Endemicity}

The level of endemicity in the Turkish flora is remarkably. About 3500 endemic taxa have been recorded representing $34 \%$ of the overall native flora. The richest family in terms of the number of endemic species is Compositae, whilst the family Campanulaceae boats the higher percentage of endemics. Within individual genera, Astragalus contains the greatest number of endemic species. The flora includes 16 endemic genera.

Out of the seven geographical regions of the country, the Mediterranean Region boats the highest number of endemic species confined to a single region: Mediterranean Region ca 980, East Anatolia Region ca 550, Central Anatolia Region ca 360, Black Sea Region ca 300, Aegean Region ca 260, Marmara Region ca 170, and Southeast Anatolia Region ca 80.

The remaining endemic taxa occurs in more than one geographical region. The highest level of endemism within Turkey is concentrated to certain specific areas, notably in Mediterranean region: the Amanos Mountain the Central Taurus Mountain, Taşeli Plateau, Bolkar and Aladağlar, Southern Western Anatolia (Antalya, Muğla and Burdur).

\section{Geophytes}

In the world, the highest geophyte diversity concentrates in the five typically Mediterranean-climate areas, where cool moist winters alternate with hot dry summers. They are: 1. Cape Region, 2. Mediterranean basin, 3. SW Australia, 4. W Chile, 5. California. The Mediterranean basin is home of the World's second richest geophyte flora where Turkey is in the center. In the flora of Turkey and the East Aegean Islands monocot and dicot geophytes totally 1060 taxa. In the Mediterranean Floristic Region 752 monocot taxa of which 564 are geophytes occur. 
198 Özhatay \& al.: Mediterranean flora and its conservation in Turkey: with special ...

Table 1. List of petaloid monocots genera in Turkey.

\begin{tabular}{|l|l|l|}
\hline AMARYLLIDACEAE & LILIACEAE & ORCHIDACEAE \\
Galanthus & Allium & Aceras \\
Ixiolirion & Anthericum & Anacamptis \\
Leucojum & Asphodeline & Barlia \\
& Asphodelus & Cephalanthera \\
Narcissus & Bellevalia & Coeloglossum \\
Pancratium & Chionodoxa & Comperia \\
Sternbergia & Colchicum & Corallorhiza \\
& Convollaria & Dactylorhiza \\
ARACEAE & Fritillaria & Epipactis \\
Acorus & Gagea & Epipogium \\
Arisarum & Hyacinthella & Gennaria \\
Arum & Hyacinthus & Goodyera \\
Biarum & Lilium & Gymnadenia \\
Dracunculus & Merendera & Himantoglossum \\
Eminium & Muscari & Limodorum \\
IRIDACEAE & Nectaroscordum & Listera \\
Crocus & Ornithogalum & Neottia \\
Gladiolus & Polygonatum & Neotinea \\
Gynandiris & Puschkinia & Ophrys \\
Irts & Scilla & Orchis \\
Romulea & Tulipa & Platanthera \\
& Urginea & Serapias \\
& Veratrum & Spiranthes \\
& & Steveniella \\
& & Traunsteinera \\
\hline
\end{tabular}

\section{Results}

Turkey is one of the most important temperature countries on earth in terms of plant diversity. The diversity of vascular plants of the country has been documented in the flora of Turkey and the East Aegean Islands edited by Prof. Peter H. Davis and published in nine volumes between 1965 and 1985. With the publication of this flora, so interest in Turkey's rich plant diversity has been brought to the attention of Turkish and foreign botanists, and its subsequent study has greatly increased our knowledge of the flora with the addition of many new taxa. The identification of these additional taxa has necessitated the publication of the supplementary volumes to the Flora of Turkey: vol. 10 published in 1988 (Davis, Mill \& Tan) and vol.11 in 2000 (Güner, Özhatay, Ekim \& Başer). Collectively the 11 volumes describe 8796 species. The flora of Turkey continues to grow and after the publication of the 11th volume, 900 new taxa were added either as a new for plant science or new records for the Turkish flora. $25 \%$ of the additional taxa come from Mediterranean floristic region of Turkey, and $73 \%$ of these are Monocotyledones. The numbers of total taxa and additional taxa are shown by the bar charts for each genus of Monocots in Fig. 3. 


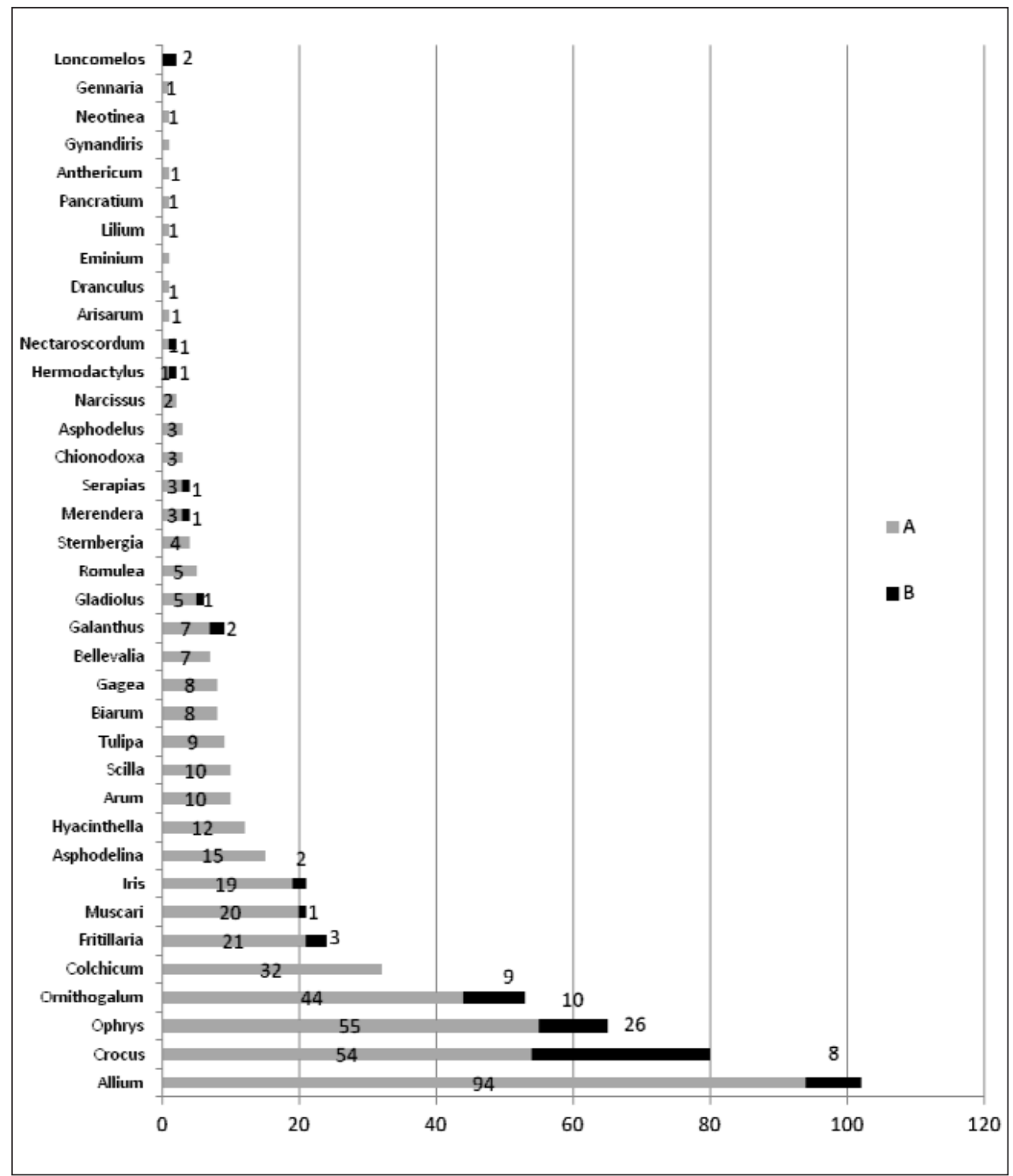

Fig. 3. A) Number of all taxa to Mediterranean Turkey, B) Additional taxa from 2000 to 2013.

\section{Mediterranean petaloid geophytes and their additional taxa with their distribution}

A total of 68 geophytes which belong to 15 genera additional to the Flora of Turkey and described as new or recorded as new for the Flora of Turkey from 2000 to 2013 are listed in alphabetical order below. Their distribution in the country and their corresponding bibliographical references are indicated. 
Allium L. (Fig. 4)

A. antalyense Eren, Çinbilgel et Parolly [Parolly \& Eren 2007].

A. arsuzense Eker \& Koyuncu [Koyuncu \& Eker 2011].

A. bilgeiae Yıldırımlı [Yıldırımlı 2012].

A. circinnatum Sieber subsp. evae R.M.Burton [Burton 2006].

A. dentiferum Webb \& Berthel. [Kocyiğit \& Özhatay 2010].

A. dodecanesii Karavokyrou \& Tzanoudakis [Kocyiğit \& Özhatay 2010].

A. elmaliense İ.G.Deniz \& Sümbül [Deniz \& Sumbul 2004].

A. roseum subsp. gulekense Koyuncu \& Eker [Koyuncu \& Eker 2011].

Crocus L. (Fig. 5, 6)

C. antalyensis B. Mathew subsp. gemicii L. Sik \& O. Erol [Erol \& al. 2011].

C. antalyensis B. Mathew subsp. striatus Erol \& Koçyiğit [Erol \& al. 2010].

C. babadagensis Kerndorff \& Pasche [Kerndorff \& al. 2012].

C. beydaglarensis Kerndorff \& Pasche [Kerndorff \& al. 2011].

C. biflorus Mill. subsp. atrospermus Kernd. \& Pasche, [Kerndorff \& Pasche 2003].

C. biflorus Mill. subsp. caelestis Kernd. \& Pasche, [Kerndorff \& Pasche 2006].

C. biflorus Mill. subsp. caricus Kernd. \& Pasche, [Kerndorff \& Pasche 2004].

C. biflorus Mill. subsp. ionopharynx Kernd. \& Pasche, [Kerndorff \& Pasche 2004].

C. biflorus Mill. subsp. leucostylosus Kernd. \& Pasche, [Kerndorff \& Pasche 2003].

C. biflorus Mill. subsp. yataganensis Kernd. \& Pasche, [Kerndorff \& Pasche 2006].

C. chrysanthus (Herbert)Herbert subsp. chrysanthus var. atroviolaceus F. Candan \& N. Özhatay [Candan \& Özhatay 2013].

C. chrysanthus (Herbert) Herbert subsp. chrysanthus var. bicoloraceus F. Candan \& N. Özhatay [Candan \& Özhatay 2013].

C. chrysanthus (Herbert) Herbert subsp. kesercioglui F. Candan \& N. Özhatay [Candan \& Özhatay 2013].

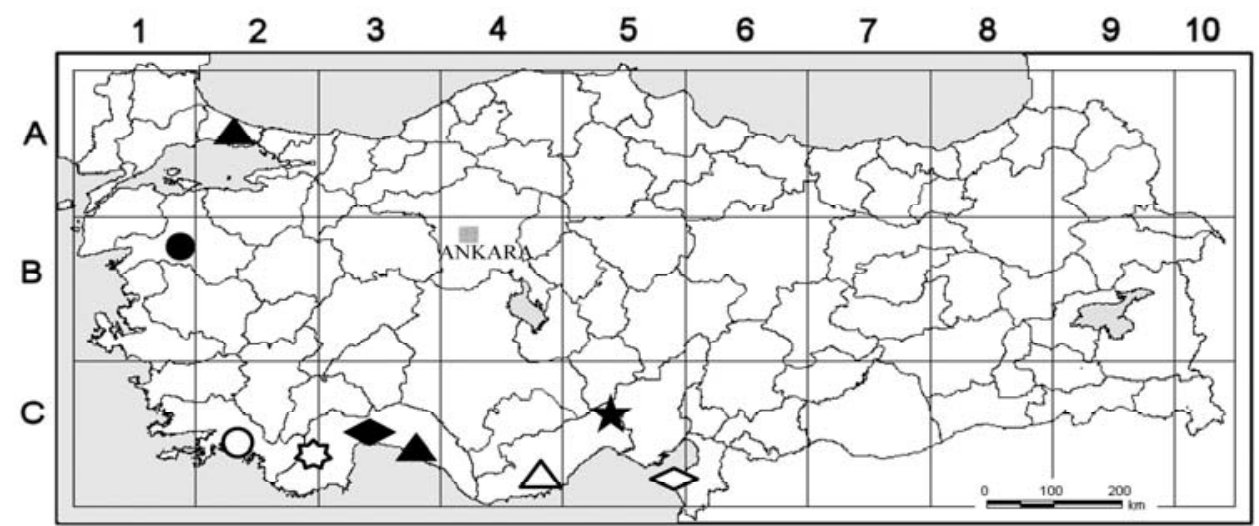

Fig. 4. Distribution in the Mediterranean floristic region of additional Allium taxa; A. antalyense, $\diamond_{A}$. arsuzense,

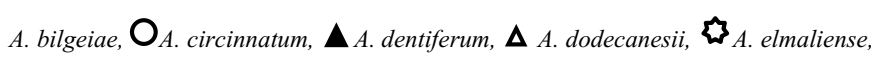




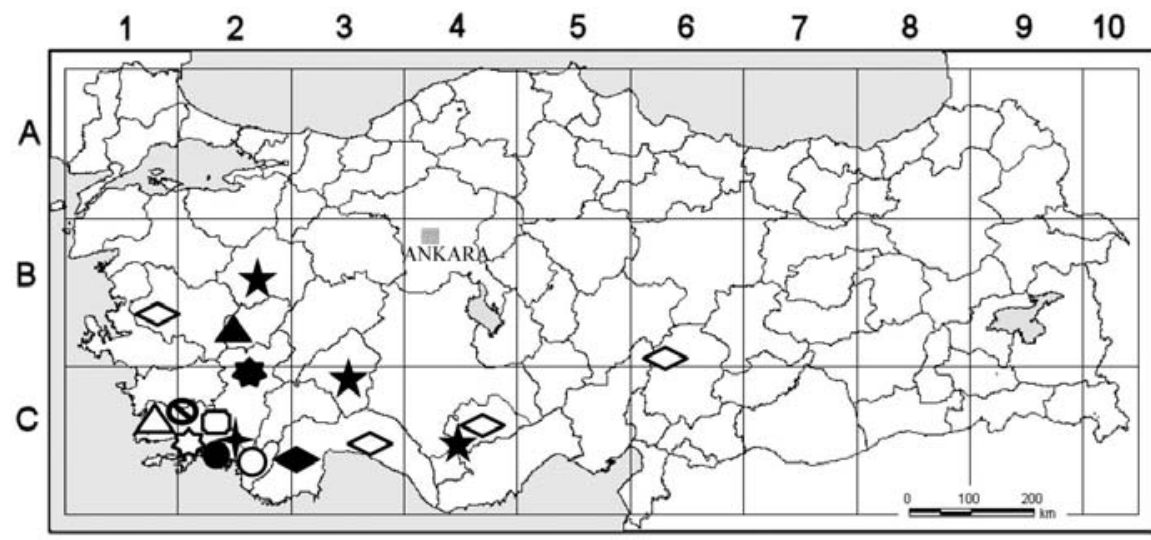

Fig. 5. Distribution in the Mediterranean floristic region of additional Crocus taxa.

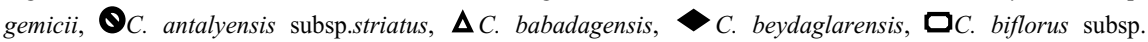
atrospermus, $\mathbf{\Delta}$ C. biflorus subsp. caelestis, $\boldsymbol{\beta}_{C}$. biflorus subsp. caricus, - C. biflorus subsp. ionopharynx, C. biflorus subsp. leucostylosus, $\mathbf{O}_{C}$. biflorus subsp. yataganensis, $\boldsymbol{t}_{C \text {. chrysanthus subsp. chrysanthus }}$ var. atroviolaceus, $\diamond_{C}$. chrysanthus subsp. chrysanthus var. bicoloraceus.

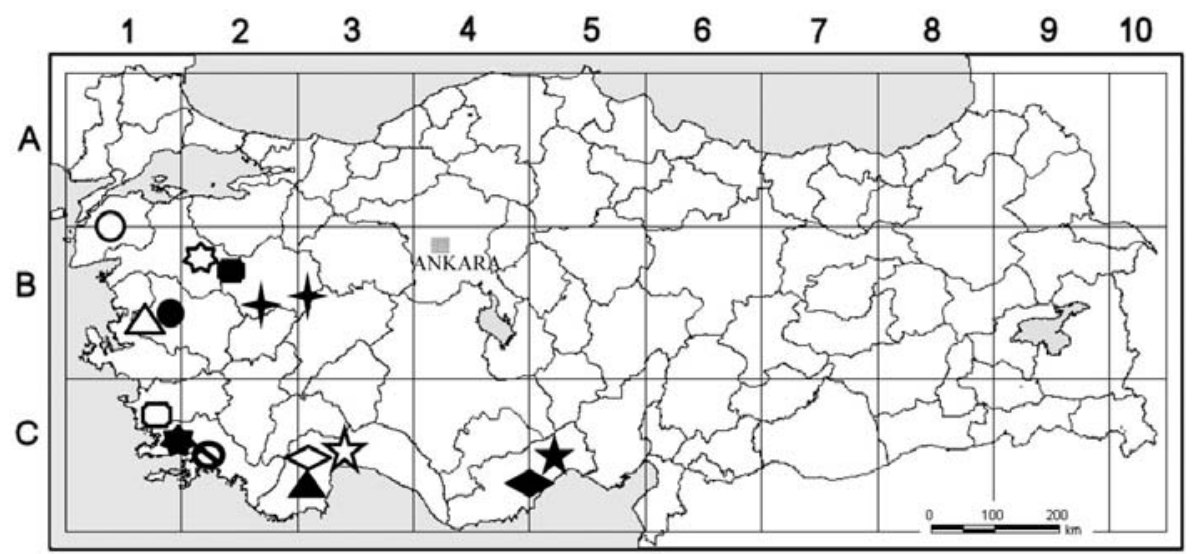

Fig. 6. Distribution in the Mediterranean floristic region of other additional Crocus taxa (2).

$\boldsymbol{\Theta}_{C .}$ chrysanthus subsp. kesercioglui, $\boldsymbol{\gamma}_{\text {C. chrysanthus subsp. punctatus, }} \boldsymbol{O}_{\text {. chrysanthus subsp. sipyleus, }} \mathbf{O}_{C}$.

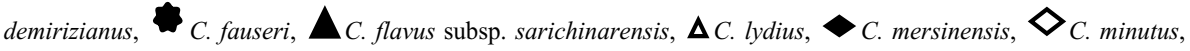

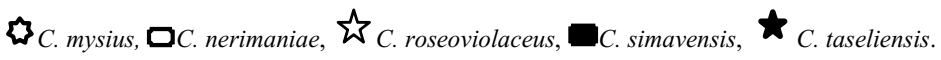


C. chrysanthus (Herbert) Herbert subsp. punctatus F. Candan \& N. Özhatay [Candan \& Özhatay 2013].

C. chrysanthus (Herbert) Herbert subsp. sipyleus F. Candan \& N. Özhatay, [Candan \& Özhatay 2013].

C. demirizianus O. Erol \& L. Can [Erol \& al. 2012].

C. fauseri Kerndorff \& Pasche [Kerndorff \& al. 2011].

C. flavus subsp. sarichinarensis Ruksans, [Ruksans 2010].

C. lydius Kerndorff \& Pache, [Kerndorff \& al. 2011].

C. mersinensis Kerndorff \& Pasche [Kerndorff \& al. 2012].

C. minutus Kerndorff \& Pasche [Kerndorff \& Pasche 2011].

C. mysius Kerndorff \& Pasche [Kerndorff \& al. 2012].

C. nerimaniae Yüzb., [Yüzbaşığlu \& Varol 2004].

C. roseoviolaceus Kerndorff \& Pasche [Kerndorff \& Pasche 2011].

C. simavensis Kerndorff \& Pasche [Kerndorff \& al. 2012].

C. taseliensis Kerndorff \& Pasche [Kerndorff \& al. 2012].

Fritillaria L. (Fig. 7)

F. frankorum R. Wallis \& R.B.Wallis [Wallis \& Wallis 2003].

F. milasense M.Tekşen \& Aytaç [Tekşlen \& Aytaç 2004].

F. mughlae Tekşen \& Aytaç [Tekşen \& Aytaç 2008].

Galanthus L. (Fig. 7)

Galanthus elwesii Hook. f. var. monostictus P.D.Sell [Sell \& Murrell 1996]

G. trojanus A.P. Davis \& N. Özhatay, [Davis \& Özhatay 2001].

Gladiolus L. (Fig. 7)

G. osmaniyensis Sağıroğlu, [Sağıroğlu \& Akgül 2013].

Hermodactylus Miller (Fig. 7)

H. tuberosus (L.) Miller var. longifolius (Sweet) Baker [Tuzlacı \& Bulut, 2012].

Iris L. (Fig. 7)

I. masia Dykes subsp. dumaniana Güner [Güner (ed.) 2012].

Limodorum Boehmer (Fig. 7)

L. rubriflorum Bartolo\&Pulvirenti [Bartolo \& Pulvirenti 1999].

Loncomelos Raf. (Fig. 7)

L. tardus Speta [Speta 2006].

L. amplificatum Speta [Speta 2010].

Merendera Ramond (Fig. 7)

M. figlalii Varol [Varol 2005a].

Muscari Miller (Fig. 7)

M. babachii Eker \& Koyuncu [Eker \& Koyuncu 2008]. 


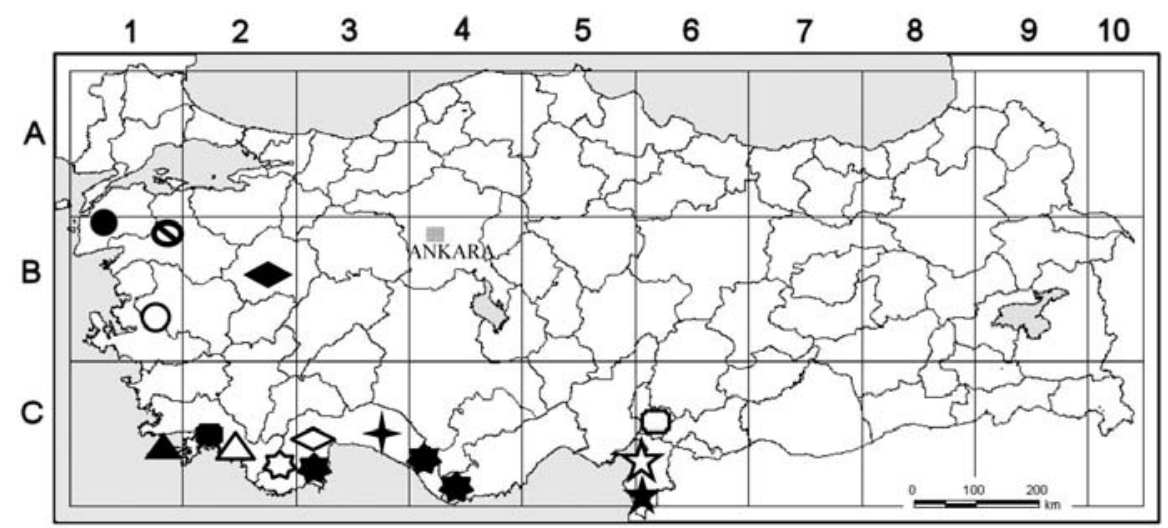

Fig.7. Distribution in the Mediterranean floristic region of additional Fritillaria, Galanthus, Gladiolus, Hermodactylus, Iris, Limodorum, Loncomelos, Merendera, Muscari and Nectaroscordum taxa; $\boldsymbol{t}_{\text {Fritillaria }}$

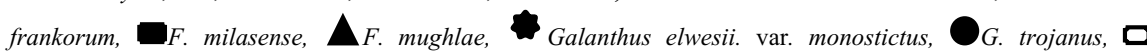
Gladiolus osmaniyensis, $\mathbf{O}_{\text {Hermodactylus tuberosus var. longifolius, }} \diamond_{\text {Iris masia subsp. dumaniana, }}$

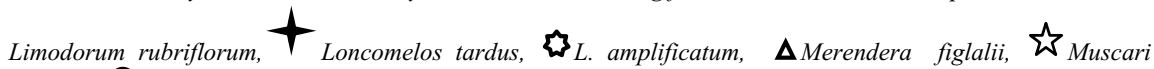
babachii, $\mathbf{\Theta}_{\text {Nectaroscordum cigdemiae. }}$

Nectaroscordum Lindl. (Fig. 7)

N. cigdemiae Y1ld. [Y1ldırımlı 2012].

\section{Ophrys L. (Fig. 8)}

O. argolica H.Fleischm. ex Vierh. subsp. mandalyana (B.\& H.Baumann) Kreutz [Kreutz 2006)].

O. attaviria D. \& U.Ruckbrodt \& D. \& S. Wenker subsp. cesmeensis C.A.J. Kreutz [Kreutz 1998].

O. fusca Link subsp. thracica Kreutz [Kreutz 2007].

O. herae M.Hirth\&H.Spaeth subsp. osmaniaca Kreutz, [Kreutz 2011].

O. lapethica Gölz \& H.R. Rinhard subsp. pamphylica Kreutz [Kreutz 2011].

O. iceliensis C.A.J. Kreutz [Kreutz 2000].

O. lyciensis H.F.Paulus, E.Gügel,D.\&U.Rückbrodt [Paulus \& al. 2001].

O. fuciflora (F. W. Schmidt) Moench subsp. pallidiconi Faurh., [Faurholdt 2011].

O. $x$ gennarii Rchb.f. nothosubsp. kusadasiensis B. Baumann \& H. Baumann [Baumann \& Lorenz 2005].

O. x rueckbrodtiana W.Hahn [Hahn 2007].

Ornithogalum L. (Fig. 9)

O. anamurense Speta [Speta 2000].

O. beyazoglui Y.Bağc1, Savran \& O. D. Düşen [Bağc1 \& al. 2011].

O. boucheanum (Kunth) Asch. [Dalgıç \& al. 2006].

O. isauricum O.D.Düşen \& H.Sümbül [Düşen \& Sumbul 2003].

O. mekselinae Varol [Varol 2005b].

O. pamphylicum O.D.Düşen \& H.Sümbül [Düşen \& Sümbül 2002]. 


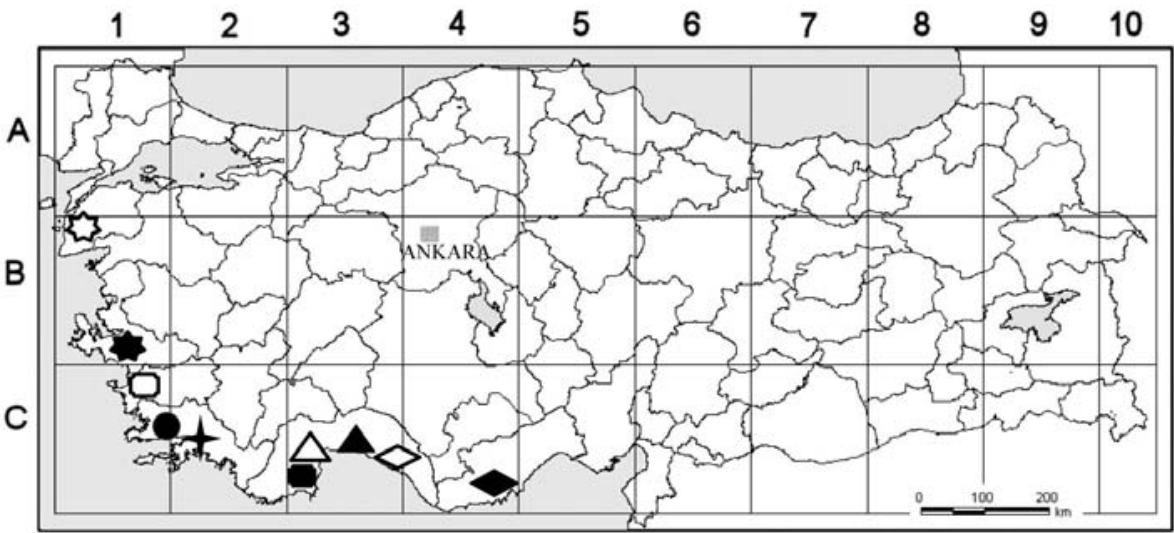

Fig. 8. Distribution in the Mediterranean floristic region of additional Ophrys taxa;

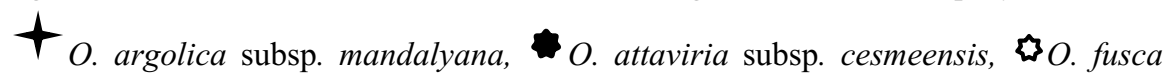
subsp. thracica, $\mathbf{\Delta}$ O. herae subsp. Osmaniaca, $\mathbf{\Delta}$ O. lapethica subsp. pamphylica, O. iceliensis, $\diamond_{O}$. lyciensis, $\boldsymbol{O}$. fuciflora subsp. pallidiconi, $\mathbf{0}$ O. $x$ gennarii nothosubsp. kusadasiensis, O. $x$ rueckbrodtiana.

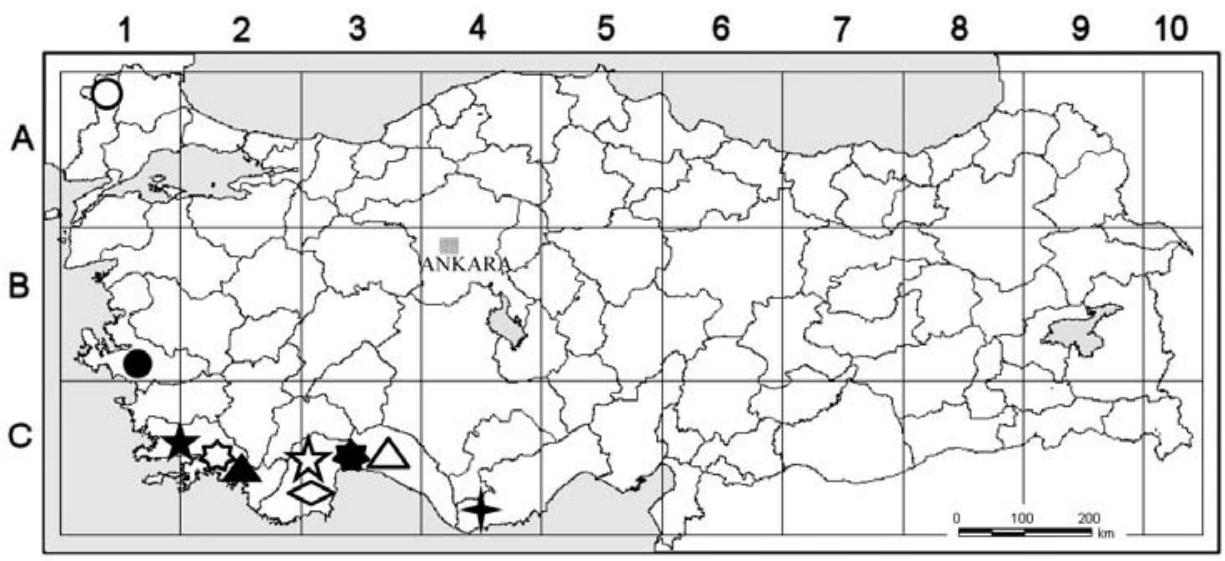

Fig. 9. Distribution in the Mediterranean floristic region of additional Ornithogalum and Serapias taxa; + Ornithogalum anamurense, O. beyazoglui, OO. boucheanum, $O$. isauricum, $\boldsymbol{\otimes}$ O. mekselinae, $\Delta$ O. pamphylicum, $\mathbf{\Delta}$ O. sandrasicum, $\boldsymbol{\diamond}_{\text {O. sphaerolobum, }}$ 柁 O. sumbulianum, Serapias vomeracea subsp. artemisiae. 
O. sandrasicum Y1ld. [Y1ldırıml1 2009a].

O. sphaerolobum Zahar. [Speta 2000].

O. sumbulianum O.D.Düşen et I.G.Deniz [Düşen \& Deniz 2005].

Serapias L. (Fig. 9)

S. vomeracea subsp. artemisiae W.Hahn, Kreutz \& Passin [Kreutz 2007].

\section{Threats}

Main threats of the area include urban and industrial development, road building, drainage of coastal and inland wetlands, dam construction on main rivers, overgrazing, afforestation of sand dunes, unsympathetic forest management, extension of intensive agriculture, tourism and recreational activities, sand and mineral extraction, and the collection of wild plants species. The fact that the flora is so rich and that new species continue to be discovered with astonishing frequency, in part reflects the sheer scale of many of the seminatural habitats present in Turkey. Yet, in spite of this apparently limitless natural resource many habitats and species are under severe threats. The losses of irreplaceable habitats much over the past few decades, have taken place at a catastrophic level. For example 79\% of sand dunes, $85 \%$ of the headlands and $80 \%$ of peatlands have been lost. 1.3 million ha of wetlands have been destroyed since 1960 .

\section{Conservation}

The "biodiversity hotspots" concept is one of the most successful tactics developed to safeguard the plant diversity richness and most endangered areas on Earth. Turkey has the richest flora in the temperate zone with approximately 10.000 vascular plants, and one third of its flora $(34.4 \%)$ is endemic to the country. Along with its rich flora, it also has a wide diversity of habitats. However, the unique flora and habitats of Turkey are being threatened and have declined rapidly over the last 40 years.

In order to protect the exceptional botanical diversity of countries across the globe, IUCNthe World Conservation Union and WWF-the World Wide Fund for Nature set up their Centers of Plant Diversity Project in the 1985, with the specific aim of listing 'all the major botanical sites and vegetation types considered to be of international importance for the conservation of plant diversity'. In 1994, the first inventory of 'Centers' was published, listing sites in Europe, Africa, Southwest Asia and the Middle East (Davis \& al. 1994). Four Centers of Plant Diversity covering $250.000 \mathrm{~km}^{2}$ should lie within the Mediterranean Region of Turkey. If these 250.000 $\mathrm{km}^{2}$ were received protection, over one-third of Turkey's land surface would be affected.

Important Plant Area (IPA) is a natural or seminatural site supporting significant population threatened plant species and/or exhibiting exceptional botanical richness particular assemblages of rare and/or containing vegetation of high botanic value. Turkey was the first country to complete a national inventory of Important Plant Areas following a partnership project undertaken DHKD (Nature Protection Society of Turkey), FFI (Fauna Flora International), ISTE (Herbarium of Faculty of Pharmacy, Istanbul University) in 1990s. 144 IPAs have been identi- 
fied in Turkey since 2003 covering 11.301 .000 hectares, this is, 13\% of Turkey's total area. Approximately $60 \%$ of the Turkish IPAs are the Mediterranean region (Byfield \& al. 2010).

\section{References}

Bağc1, Y., Savran, A., Düşen, O.D. \& Tutar, L. 2011: Ornithogalum beyazoglui (Hyacinthaceae), a new species from West Anatolia, Turkey. - Bangl J. Plant Taxon 18(1): 51-55. doi: 10.3329/bjpt.v18i1.7838

Bartolo, G. \& Pulvirenti, S. 1999: Limodorum rubriflorum (Orchidaceae): a new species from the Eastern Mediterranean area. - Caesiana 12: 1-10.

Baumann, H. \& Lorenz, R. 2005: Beitrage zur Taxonomie europaischer und mediterraner Orchideen. - J. Eur. Orch. 37: 939-974.

Burton, R. 2006: A new subspecies of Allium circinnatum Sieber from S.W. Turkey. - Ann. Mus. Goulandris 11: 81-84.

Byfield, A., Atay, S. \& Özhatay, N. 2010: Important Plant Areas in Turkey: 122 Key Turkish Botanical Sites. - İstanbul.

Candan, F. \& Özhatay, N. 2013: Crocus chrysanthus s. lato (Iridaceae) in Turkey. - Ann. Bot. Fenn 50: 423-430. doi: 10.5735/085.050.0610

Dalgıç, G., Dane, F. \& Aksoy, O.D. 2006: A new record for the flora of Turkey: Ornithogalum boucheanum (Hyacinthaceae). - Pp. 169-173 in: Proceedings of IV BBC. - Sofia.

Davis, A. P. \& Özhatay, N. 2001: Galanthus trojanus: a new species of Galanthus (Amaryllidaceae) from north-western Turkey. - Bot. J. Linn. Soc.137: 409-412.

Davis, P. H., Harper, P .C. \& Hedge, J. C. (eds). 1971: Plant Life of South-West Asia. - Edinburgh.

Davis, S. D., Heywood, V. H. \& Hamilton, A. C. 1994: Centres of Plant Diversity Volume 1: Europe, Africa, South West Asia and the Middle East WWF \& IUCN. - Cambridge.

Deniz, İ. G. \& Sümbül, H. 2004: Allium elmaliense (Alliaceae), a new species from SW Anatolia, Turkey. - Ann. Bot. Fennici 41: 147- 150.

Düşen, O. D. \& Deniz, I. G. 2005: Ornithogalum sumbulianum (Hyacinthaceae), a new endemic species from South West Anatolia. - Pak. J. Bot. 37: 33-36.

—\& Sümbül, H. 2002: Ornithogalum pamphylicum: New species from South Anatolia. - Isr. J. Plant Sci. 50: 73-76.

— \& - 2003: A new Ornithogalum L. species (Liliaceae) from Turkey. - Isr. J. Plant Sci. 51: 75-77.

Eker, İ. \& Koyuncu, M. 2008: Muscari babachii sp. nov. (Hyacinthaceae) from South Anatolia. Nord. J. Bot. 26: 49-52. doi: 10.1111/j.1756-1051.2008.00299.x

Erol, O., Can, L. \& Şık, L. 2012: Crocus demirizianus sp. nov. From Northwestern Turkey. - Nord. J. Bot. 30: 665-667. doi: 10.1111/j.1756-1051.2012.01684.x

—, Koçyiğit, M., Şık, L., Özhatay, N. \& Küçüker, O. 2010: Crocus antalyensis subsp. striatus subsp. nov. (Iridaceae) from southwest Anatolia. - Nord. J. Bot. 28: 186-188. doi: 10.1111/j.17561051.2009.00447.x

—, Şık, L., Kaya, B. H., Tanyolaç, B. \& Küçüker, O. 2011: Genetic diversity of Crocus antalyensis B. Mathew (Iridaceae) and a new subspecies from southern Anatolia. - Pl. Syst. Evol. 294: 281-287. doi: 10.1007/s00606-011-0465-8

Faurholdt, N. 2011: Ophrys fuciflora subsp. pallidiconi a new subspecies from Turkey. - J. Eur. Orch. 43(3): 560-566.

Güner, A., Aslan, S., Ekim, T., Vural, M. \& Babaç, M. T. (edlr.). 2012: Türkiye Bitkileri Listesi (Damarlı Bitkiler). - Yayını. 
Hahn, W. 2007: Ophrys x rueckbrodtiana, nothospecies nat. Nova; eine Ophrys-Hybride aus der Südtürkei. - Ber Arbeitskrs Heim Orchid 24: 122-126.

Kerndorff, E. \& Pasche, E. 2011: Two new taxa of Crocus (Liliiflorae, Iridaceae) from Turkey. Sapfia 95: 2-5.

Kerndorff, H. \& Pasche, E. 2003: Crocus biflorus in Anatolia. — The Plantsman N.S. 8: 77-89.

— \& - 2004: Two new taxa of the Crocus biflorus Aggregate (Liliiflorae, Iridaceae) from Turkey.

- Linzer biol Beitr 36/1: 5-10.

— \& - 2006: Crocus biflorus (Liliiflorae, Iridaceae) in Anatolia (Part three). - Linzer biol Beitr 38/1: 165-187.

—, 一, Harpke, D. \& Blattner, F. R. 2011: Three new species of Crocus (Liliiflorae, Iridaceae) from Turkey. - Stapfia 95: 99-105.

—, —, — \& - 2012: Seven new species of Crocus (Liliiflorae, Iridaceae) from Turkey. - Stapfia 97: 3-16.

Koçyiğit, M. \& Özhatay, N. 2010: A contribution to the genus Allium L. (Sect. Codonoprasum) Turkey. - Turk. J. Bot. 34: 391-395. doi: 10.3906/bot-0907-91

Koyuncu, M. \& Eker, I. 2011: Allium arsuzense sp. nov. and A. roseum subsp. gulekense subsp. nov. from Turkey. - Nord. J. Bot. 29: 391-396. doi: 10.1111/j.1756-1051.2011.00879.x

Kreutz, C. A. J. 1998: Die Orchideen der Türkei. - Landgraaf.

- 2000: Ophrys iceliensis, eine neue Art aus der mittleren Südtürkei. - J. Eur. Orch. 32: 527-537.

- 2006: Orchideen Europas-Beitrage, umkombinationen und kurze Bemerkungen. - The Orchidee 57: 99-104.

- 2007: Beitrag zur Taxonomic und Nomenklatur europaischer, mediterraner, nordafrikanischer und vorderasiatischer Orchideen. - Ber Arbeitskrs Heim Orchid 24: 77-141.

- 2011: Beitrag zur Kenntnis europäischer, mediterraner und vorderasiatischer Orchideen. - Ber. Arbeitskrs. Heim. Orchid. 28(2): 263-299.

Parolly, G. \& Eren, Ö. 2007: Contributions to the flora of Turkey. 2. - Willdenowia 37: 243-271.

Paulus, H. F., Gügel, E., Rückbrodt, D. \& Rückbrodt, U. 2001: Ophrys lyciensis H.F. Paulus, E.Gügel, D. Rückbrodt \& U. Rückbrodt spec. nov., eine neue Art aus dem Ophrys holosericaArtenkreis der STürkei (Orchidaceae). - Ber. Arbeitskrs. Heim. Orchid. 18: 19-33.

Ruksans, J. 2010: Crocuses. A complete quide to the genus. - Portland.

Sağıroğlu, M. \& Akgül, G. 2013: Gladiolus osmaniyensis (Iridaceae), a new species from South Anatolia, Turkey. — Turk J Bot. 38: 31-36. doi:10.3906/bot-1209-60.

Sell, P. D. \& Murrell, G. 1996: Flora of Great Britain and Ireland. - Cambridge.

Speta, F. 2000: Ornithogalum sphaerolobum und seine Dappelgönger. - Preslia 72: 369-398.

- 2006: Die Gattung Loncomelos Raf. (Hyacinthaceae-Ornithogaloideae), vorgestellt anhand dreier neuer Arten. - Phyton 46: 1-25.

- 2010: Beitrag zur Kenntnis der Loncomelos narbonensis-Verwandtschaft (HyacinthaceaeOrnithogaloideae). - Verh.zool.-bot.Ges.Wien 147: 125-157.

Tekşen, M. \& Aytaç, Z. 2004: New Fritillaria L. taxa from Turkey. - Isr. J. Plant Sci. 52: 347-355. — \& - 2008: Fritillaria mughlae (Liliaceae), a new species from Turkey. -Ann Bot Fenn 45: 141147. doi: 10.5735/085.045.0209

Tuzlac1, E. \& Bulut, G. 2012: Türkiye Florası için üç yeni kayıt. - XX. Bitkisel İlaç Hammaddeleri Toplantıs1 (Bihat 2012) Bildiri Kitab1 s.121.

Varol, Ö. 2005a: Merendera figlalii (Colchicaceae) a new species from Southwestern Anatolia, Turkey. - Belg. J. Bot. 138: 89-92.

- 2005b: Ornithogalum mekselinae (Liliaceae), a new species from south-western Anatolia, Turkey. - Nord. J. Bot. 23: 607-609.

Wallis, R. \& Wallis, R. B. 2003: Fritillaria frankorum, a new species. - The Plantsman 2: 15-17. 
208 Özhatay \& al.: Mediterranean flora and its conservation in Turkey: with special ...

Yıldırıml1, Ş. 2009: A new species of Ornithogalum, O. sandrasicum Yıld. (Liliaceae) from SW Anatolia, Turkey. - Ot Sist. Bot. Dergisi 16: 1-8.

- 2012: Nine new species from Kaz dağları, Munzur dağları, Bolkar dağları and Karçal dağları, Turkey. - Ot Sist. Bot. Dergisi 19(1): 1-34.

Yüzbaş1oğlu, S. \& Varol, Ö. 2004: A new autumn-flowering Crocus from SW Turkey. -Plantsman N.S. 3: $104-106$.

Address of the authors:

Neriman Özhatay, Mine Koçyiğit, Sırrı Yüzbaşığlu, Bahar Gürdal,

İstanbul Üniversitesi, Eczacılık Fakültesi, Farmasötik Botanik Anabilim Dalý, Beyazıt 34116 İstanbul. E-mail: nozhatay@istanbul.edu.tr 